\title{
Role of DFNA5 in hearing loss and cancer - a comment on Rakusic et al
}

This article was published in the following Dove Press journal:

OncoTargets and Therapy

15 September 2015

Number of times this article has been viewed

\section{Lieselot Croes ${ }^{1,2}$ \\ Ken Op de Beeck ${ }^{1,2}$ Guy Van Camp'}

'Center of Medical Genetics (CMG), Department of Biomedical Sciences, University of Antwerp, Antwerp, Belgium; ${ }^{2}$ Center for Oncological Research (CORE), Department of Medicine, University of Antwerp, Antwerp, Belgium
Correspondence: Lieselot Croes University of Antwerp, Center of Medical Genetics (CMG) and Center for Oncological Research (CORE), Universiteitsplein I, 26I0 Wilrijk,

Antwerp, Belgium

Tel +32 3275 978I

Email lieselot.croes@uantwerpen.be

\section{Dear editor}

We would like to comment on the paper published by Rakusic et al about sudden bilateral hearing loss in gastric cancer as the only symptom of disease. ${ }^{1}$ The authors state that "Inactivated DFNA5, otherwise described in hereditary bilateral deafness, perhaps favors the development of deafness in patients with gastric cancer". ${ }^{1}$ We believe this conclusion is erroneous. Although DFNA5 has been implicated in both hearing loss and cancer, the underlying molecular mechanisms are different and completely opposite (Figure 1).

In 1998, we identified the first DFNA5 mutation in a Dutch family, as a cause for a specific form of progressive, sensorineural, and non-syndromic hearing loss. ${ }^{2}$ This type of hearing loss is inherited in an autosomal dominant manner. Afterward, other families were reported with hearing loss due to DFNA5 mutations. ${ }^{3-8}$ Although all these DFNA5 mutations are different on DNA level, they all result in skipping of exon 8 on mRNA level, and have an identical effect on the protein. ${ }^{9}$

The DFNA5 mutation leading to hearing loss is thought to be an activating, gain of function mutation. As the DFNA5 protein has an apoptosis inducing capacity, the effect is expected to be an increase in apoptosis, possibly leading to hearing loss by apoptosis of cells crucial for hearing, such as cochlear hair cells (Figure 1). ${ }^{10}$

Since 1998, a number of papers on DFNA5 have been published, pointing toward an involvement in cancer. ${ }^{9-20}$ Here the molecular mechanism is different. DFNA5 becomes inactivated through DNA promotor methylation. Because of the inactivation, DFNA5 loses its capacity to induce apoptosis and most likely contributes to tumorigenesis in this manner (Figure 1).

In conclusion, a very specific gain of function mutation in DFNA5 leads to hearing loss, while inactivation of DFNA5 on the epigenetic level (DNA methylation) plays a role in cancer. Therefore, in our opinion, the observed sudden bilateral deafness in the 60-year-old woman is not caused by inactivation of DFNA5. Akino et al showed that DFNA5 is methylated in $52 \%$ of primary gastric cancers and

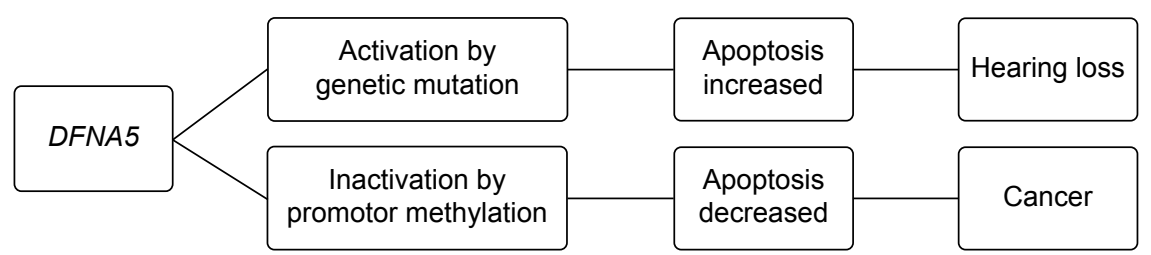

Figure I Possible mechanism of DFNA5 in hearing loss and cancer. 
was correlated with positivity for Epstein-Barr virus and the absence of metastasis. ${ }^{14}$ In patients with metastasized gastric cancer the incidence of DFNA5 methylation was $16.7 \%(2 / 12) .{ }^{14}$ The observation that DFNA5 is inactivated in this woman is thus not exceptional and in agreement with the literature. However, as described above, inactivation of DFNA5 is very unlikely to be the cause of the observed hearing loss.

\section{Disclosure}

The authors have no conflict of interest to disclose in this correspondence.

\section{References}

1. Rakusic Z, Krpan AM, Polancec DS, Jakovcevic A, Bisof V. Sudden bilateral hearing loss in gastric cancer as the only symptom of disease. Onco Targets Ther. 2015;8:1285-1289.

2. Van Laer L, Huizing EH, Verstreken M, et al. Nonsyndromic hearing impairment is associated with a mutation in DFNA5. Nat Genet. 1998;20(2):194-197.

3. Yu C, Meng X, Zhang S, Zhao G, Hu L, Kong X. A 3-nucleotide deletion in the polypyrimidine tract of intron 7 of the DFNA5 gene causes nonsyndromic hearing impairment in a Chinese family. Genomics. 2003;82(5):575-579.

4. Bischoff AM, Luijendijk MW, Huygen PL, et al. A novel mutation identified in the DFNA5 gene in a Dutch family: a clinical and genetic evaluation. Audiol Neurootol. 2004;9(1):34-46.

5. Cheng J, Han DY, Dai P, et al. A novel DFNA5 mutation, IVS8+4 A $>$ G, in the splice donor site of intron 8 causes late-onset non-syndromic hearing loss in a Chinese family. Clin Genet. 2007;72(5):471-477.

6. Park HJ, Cho HJ, Baek JI, et al. Evidence for a founder mutation causing DFNA5 hearing loss in East Asians. J Hum Genet. 2010;55(1): 59-62.

7. Nishio A, Noguchi Y, Sato T, et al. A DFNA5 mutation identified in Japanese families with autosomal dominant hereditary hearing loss. Ann Hum Genet. 2014;78(2):83-91.
8. Chai Y, Chen D, Wang X, Wu H, Yang T. A novel splice site mutation in DFNA5 causes late-onset progressive non-syndromic hearing loss in a Chinese family. Int J Pediatr Otorhinolaryngol. 2014;78(8): $1265-1268$.

9. de Beeck KO, Van Laer L, Van Camp G. DFNA5, a gene involved in hearing loss and cancer: a review. Ann Otol Rhinol Laryngol. 2012;121(3): 197-207.

10. Op de Beeck K, Van Camp G, Thys S, et al. The DFNA5 gene, responsible for hearing loss and involved in cancer, encodes a novel apoptosis-inducing protein. Eur J Hum Genet. 2011;19(9):965-973.

11. Thompson DA, Weigel RJ. Characterization of a gene that is inversely correlated with estrogen receptor expression (ICERE-1) in breast carcinomas. Eur J Biochem. 1998;252(1):169-177.

12. Lage H, Helmbach H, Grottke C, Dietel M, Schadendorf D. DFNA5 (ICERE-1) contributes to acquired etoposide resistance in melanoma cells. FEBS Lett. 2001;494(1-2):54-59.

13. Masuda Y, Futamura M, Kamino H, et al. The potential role of DFNA5, a hearing impairment gene, in p53-mediated cellular response to DNA damage. J Hum Genet. 2006;51(8):652-664.

14. Akino K, Toyota M, Suzuki H, et al. Identification of DFNA5 as a target of epigenetic inactivation in gastric cancer. Cancer Sci. 2007;98(1): $88-95$.

15. Kim MS, Chang X, Yamashita K, et al. Aberrant promoter methylation and tumor suppressive activity of the DFNA5 gene in colorectal carcinoma. Oncogene. 2008;27(25):3624-3634.

16. Kim MS, Lebron C, Nagpal JK, et al. Methylation of the DFNA5 increases risk of lymph node metastasis in human breast cancer. Biochem Bioph Res Commun. 2008;370(1):38-43.

17. Fujikane T, Nishikawa N, Toyota M, et al. Genomic screening for genes upregulated by demethylation revealed novel targets of epigenetic silencing in breast cancer. Breast Cancer Res Treat. 2010;122(3):699-710.

18. Yokomizo K, Harada Y, Kijima K, et al. Methylation of the DFNA5 gene is frequently detected in colorectal cancer. Anticancer Res. 2012; 32(4):1319-1322.

19. Van Rossom S, Op de Beeck K, Franssens V, et al. The splicing mutant of the human tumor suppressor protein DFNA5 induces programmed cell death when expressed in the yeast Saccharomyces cerevisiae. Front Oncol. 2012;2:77.

20. Wang CJ, Tang L, Shen DW, et al. The expression and regulation of DFNA5 in human hepatocellular carcinoma DFNA5 in hepatocellular carcinoma. Mol Biol Rep. 2013;40(12):6525-6531. 


\section{Authors' reply}

Zoran Rakusic'

Ana Misir Krpan'

Darija Stupin Polancec ${ }^{2}$

Antonia Jakovcevic ${ }^{3}$

Vesna Bisof'

'Department of Oncology, University Hospital Center Zagreb, Zagreb, Croatia; ${ }^{2}$ Fidelta Ltd. for Research and Development,

Zagreb, Croatia; ${ }^{3}$ Department of Pathology, University Hospital

Center Zagreb, Zagreb, Croatia

Correspondence: Zoran Rakusic

Department of Oncology, University Hospital Center Zagreb,

Kispaticeva 12, 10000 Zagreb, Croatia

Email zrakusic@kbc-zagreb.hr

\section{Dear editor}

We are pleased that our article has caused so much interest and especially we appreciate comments by Croes et al who are devoted to research of DFNA5 gene.

Following alignment analysis of DFNA5 coding region and our primers used in quantitative reverse transcription polymerase chain reaction we noticed that reverse primer hybridized to the nucleotide sequence within exon 8 . This could be the explanation why we obtained undetectable levels of DFNA5 on transcription level and prove that in this patient mutation in coding region and consequently exon 8 skipping, caused observed bilateral deafness. However our aim is to more precisely determine changes in coding region as well as in promoter region of DFNA5 gene which is a possible cause of gastric cancer.

Our intention was to describe a very unusual clinical presentation of gastric cancer. Patient's family history was negative for hearing impairment. Within 3 weeks she was completely deaf. Due to the uncommon symptom we questioned the potential link between hearing loss and cancer. DFNA5 analysis was made as an attempt to explain the connection.

DFNA5 is very interesting because in one gene there are two changes, hypermethylation and mutation, in two relatively remote places that lead to the opposite effects - activation and deactivation. Activation leads to deafness and deactivation to cancer. The Cancer Genome Atlas Research Network divided gastric cancers into four subtypes; Epstein-Barr virus-positive, microsatellite instability-positive, genomically stable and chromosomally unstable. ${ }^{1}$ Although contrary to previous hypothesis, ${ }^{2}$ from a clinical point of view it could be speculated that hypermethylation of promoter region leads to gastric cancer and causes chromosome instability with de novo mutation of DFNA5 gene. It remains possible that mutation became clinically apparent due to dramatic onset of hearing loss but because of the small number of patients it is impossible to prove.

Many aberrantly methylated genes are reported ${ }^{3}$ as well as DFNA5. ${ }^{3,4}$ Even though the role of DFNA5 in hereditary hearing loss as well as in carcinogenesis is well described, ${ }^{3}$ there is still a gap in knowledge to explain the mechanism of these two events occurring in the same patient. Is there any association? DNA methylation is now a topic of interest.

Many questions still remain unanswered. What about DFNA5 in normal gastric mucosa? What is the pathological finding of n. VIII (Statoacoustic nerve was unfortunately not analyzed on autopsy)? Is there Epstein-Barr virus in tumor tissue? Is there any hypermethylation of promotor region? In families with hereditary DFNA5 associated hearing loss are there any data about cancer incidence? But it is beyond the scope of our article.

\section{Disclosure}

The authors have no conflicts of interest to disclose in this correspondence.

\section{References}

1. Cancer Genome Atlas Research Network. Comprehensive molecular characterization of gastric adenocarcinoma. Nature. 2014;513(7517): 202-209.

2. de Beeck KO, Van Laer L, Van Camp G. DFNA5, a gene involved in hearing loss and cancer: a review. Ann Otol Rhinol Laryngol. 2012;121(3):197-207.

3. Shigeyasu K, Nagasaka T, Mori Y, et al. Clinical Significance of MLH1 Methylation and CpG Island Methylator Phenotype as Prognostic Markers in Patients with Gastric Cancer. PLoS One. 2015;10(6):e0130409.

4. Van Rossom S, Op de Beeck K, Hristovska V, Winderickx J, Van Camp G. The deafness gene DFNA5 induces programmed cell death through mitochondria and MAPK-related pathways. Front Cell Neurosci. 2015;9:231.

Dove Medical Press encourages responsible, free and frank academic debate. The content of the OncoTargets and Therapy 'letters to the editor' section does not necessarily represent the views of Dove Medical Press, its officers, agents, employees, related entities or the OncoTargets and Therapy editors. While all reasonable steps have been taken to confirm the content of each letter, Dove Medical Press accepts no liability in respect of the content of any letter, nor is it responsible for the content and accuracy of any letter to the editor.

OncoTargets and Therapy

Dovepress

\section{Publish your work in this journal}

OncoTargets and Therapy is an international, peer-reviewed, open access journal focusing on the pathological basis of all cancers, potential targets for therapy and treatment protocols employed to improve the management of cancer patients. The journal also focuses on the impact of management programs and new therapeutic agents and protocols on patient perspectives such as quality of life, adherence and satisfaction. The manuscript management system is completely online and includes a very quick and fair peer-review system, which is all easy to use. Visit http://www.dovepress.com/testimonials.php to read real quotes from published authors. 